\title{
GLUCOSE-DEPENDENT INSULINOTROPIC POLYPEPTIDE (GIP): DEVELOPMENT OF DPIV-RESISTANT ANALOGUES WITH THERAPEUTIC POTENTIAL
}

\author{
SIMON A. HINKE ${ }^{\mathrm{a}}$, FRANCIS LYNN ${ }^{\mathrm{a}}$, JAN EHSES ${ }^{\mathrm{a}}$, NATHALIE PAMIR ${ }^{\mathrm{a}}$, \\ SUSANNE MANHART ${ }^{\mathrm{b}}$, KERSTIN KÜHN-WACHE ${ }^{\mathrm{b}}$, FRED ROSCHE ${ }^{\mathrm{b}}$, \\ HANS-ULRICH DEMUTH ${ }^{\mathrm{b}}$, RAYMOND A. PEDERSON ${ }^{\mathrm{a}}$ and \\ CHRISTOPHER H.S. MCINTOSH ${ }^{\mathrm{a}}$ \\ ${ }^{a}$ Department of Physiology, University of British Columbia, Vancouver, \\ Canada, ${ }^{b}$ Probiodrug Research, Biocenter, Halle (Saale), Germany
}

\section{INTRODUCTION}

Glucose-dependent Insulinotropic Polypeptide $\left(\mathrm{GIP}_{1-42}\right.$; Figure 1$)$ is a gastrointestinal hormone that is released in response to nutrient intake and stimulates insulin secretion in a glucose-dependent manner ${ }^{1,2}$ and was the first established hormonal component (incretin) of the enteroinsular axis identified. Subsequently, intestinal products of the proglucagon gene, GLP- $1_{7-36}$ and GIP$17-37$ (GLP-1), were also shown to share the ability of stimulating insulin secretion and the dual actions of GIP and GLP-1 are widely considered to be the major hormonal contributors to intestinal regulation of pancreatic endocrine function.

There are two major defects in type 2 diabetes that contribute to the hyperglycemia that is characteristic of the disorder: defective responsiveness to glucose and insulin resistance. Current therapies for type 2 diabetics generally involve dietary control plus stimulants of insulin secretion (e.g. sulfonylureas) and/or insulin sensitizers (e.g. metformin, thiazolidinediones). However considerable numbers of patients become resistant to sulfonylurea action and many eventually become insulin-dependent. As a consequence, there is increasing interest in developing alternative methods for stimulating endogenous insulin secretion. Among these, there has been a major emphasis 


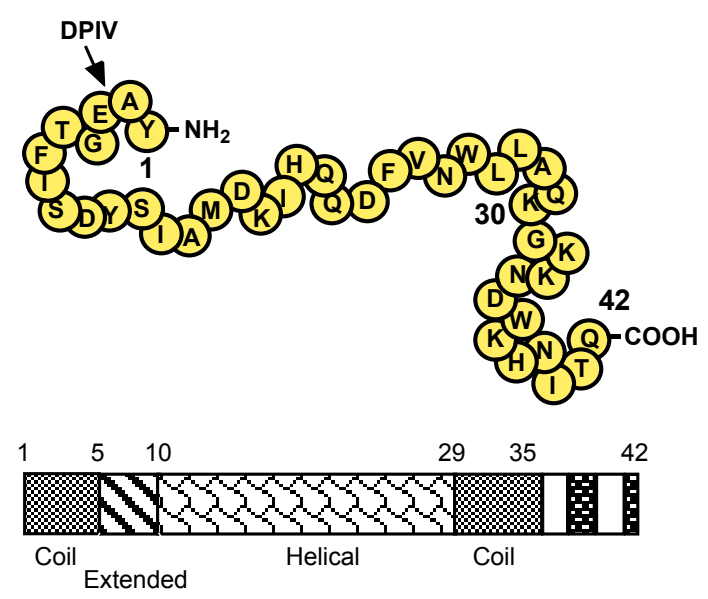

Figure 1. Predicted Secondary Structure of GIP

Secondary structure was predicted by the Gascuel and Golmard Basic Statistical Method using PCGENE. The site of DPIV-cleavage is shown.

on long-acting analogues of GLP-1 ${ }^{3}$ and, more recently, DPIV inhibitors with little interest shown in $\mathrm{GIP}^{4}$. The current short review focuses on the underlying reasons for this disinterest and attempts to provide a balanced view on the potential for DPIV-resistant analogues of GIP in the treatment of diabetes.

\section{WHY DEVELOP GIP ANALOGUES?}

GIP potently stimulates insulin secretion in humans in a glucose-dependent manner ${ }^{2}$. Additionally, recent studies have demonstrated that it stimulates beta cell mitogenesis and inhibits apoptosis ${ }^{5,6}$. GIP $1-42$ and GLP-1 are equally insulinotropic $^{7}$ and conclusions of a much greater potency of GLP-1 can be attributed to comparative studies with batches of synthetic GIP with low biological activity ${ }^{7,8}$. In addition to the common physiological actions exhibited by GIP and GLP-1, GIP also exhibits discrete actions. For example, GIP demonstrates both lipolytic and lipogenic activity on fat cells, ${ }^{4,9}$. Although the significance is not clear, one possibility is that GIP stimulates lipolysis during fasting conditions, thus providing tissues, including the $\square$-cell, with fatty acids that are essential for their normal function ${ }^{9}$. During a meal, incretins stimulate insulin secretion and GIP may then act in a lipogenic manner, as insulin inhibits the lipolytic pathway.

\section{PROBLEMS WITH GIP ANALOGUE DEVELOPMENT}

The two major arguments brought against developing analogues of GIP for 
therapeutic use are that it is rapidly degraded in the bloodstream and that type 2 diabetic patients exhibit resistance to GIP action. The first indication that GIP was a target for DPIV degradation was obtained in HPLC studies on partially purified fractions from porcine intestinal extracts ${ }^{10}$. A peptide corresponding to GIP $_{3-42}$ was identified and it was suggested that enzymatic cleavage resulted in formation of the N-terminally truncated molecule ${ }^{11}$. $\mathrm{GIP}_{3-42}$ was shown to be non-insulinotropic in the perfused rat pancreas ${ }^{10}$ and isolated islets. Mentlein et $\mathrm{al}^{12}$ first reported that $\mathrm{GIP}_{1-42}$ was a substrate for DPIV, with release of $\mathrm{Tyr}^{1}$ $\mathrm{Ala}^{2}$. Serum-degradation of GIP by DPIV was established using the inhibitor, Lys-Pyrrolidide ${ }^{12}$. The in vivo importance of DPIV-mediated degradation of GIP was demonstrated independently by following ${ }^{125} \mathrm{I}_{-\mathrm{GIP}_{1-42}}$ conversion to ${ }^{125}$ IGIP $_{3-42}$ following i.v. injection into anaesthetized rats ${ }^{13}$.

Identification of the second problem, GIP resistance, has its origins in studies by Perley and Kipnis ${ }^{14}$ in which they observed a greatly reduced incretin effect in type 2 diabetes. Studies were later performed to determine whether pathophysiological changes in GIP secretion contributed to this defect ${ }^{1,2}$ and whether responsiveness to incretins was compromised. Several groups have now shown blunted responses to GIP infusion in type 2 diabetes, although the degree of resistance observed differs between groups ${ }^{15-17}$. It is important to note that all of the studies to date have employed infusion conditions designed to produce circulating levels in the physiological range.

\section{DEVELOPMENT OF DPIV-RESISTANT GIP ANALOGUES}

The protocol that we have used for screening for DPIV-resistant analogues over the past few years can be summarized ${ }^{18,19}$ :

1. Solid phase peptide synthesis and screening for DPIV-resistance using Maldi-TOF mass spectrometry,

2. Competitive binding assays using $\mathrm{CHO}-\mathrm{K} 1$ cells transfected with the GIP receptor (GIP-R1 cells) to establish binding constants ( $\mathrm{IC}_{50}$ values).

3. Measurement of analogue-induced cyclic AMP production in CHO-K1 cells and determination of maximal response and $\mathrm{EC}_{50}$ values.

Analogues with promising characteristics in 1-3:

4. Determination of analogue-induced insulin secretion from insulinoma cells ( $\square \mathrm{TC}-3$, INS-1) and/or isolated perfused rat pancreas.

5. In vivo bioassay during an oral (OGTT) or intraperitoneal (IPGTT) glucose tolerance test in normal and diabetic rats.

Design of the GIP analogues was based on previous studies with other 
members of the secretin-glucagon family of peptides and on the basis of knowledge regarding the substrate specificity requirements of DPIV. The Nterminus of GIP is extremely sensitive to change and removal of the first two amino-terminal residues $\left(\mathrm{GIP}_{3-42}\right)$ results in a peptide that exhibits reduced receptor affinity in competitive binding studies and is completely devoid of the ability to stimulate cAMP production or affect glucose excursions and insulin profiles in vivo. Therefore, to generate DPIV-resistant GIP analogues, peptides were generated with modifications or substitutions of amino acids in positions 2 and 3. Additionally, for the majority of syntheses, the GIP ${ }_{1-30}$ backbone was used, rather than the intact peptide. Using the above screening procedure the following GIP analogues were identified as being completely or moderately DPIV-resistant and worthy of further study ${ }^{18}$ :

\begin{tabular}{|c|c|}
\hline COMPLETELY RESISTANT & MODERATELY RESISTANT* \\
\hline $\begin{array}{l}{\left[\mathrm{D}-\mathrm{Ala}^{2}\right] \mathrm{GIP}_{1-42} \text { and }\left[\mathrm{D}-\mathrm{Ala}^{2}\right] \mathrm{GIP}_{1-30}\left[\mathrm{Pro}^{2}\right]} \\
\mathrm{GIP}_{1-30} \\
{\left[\mathrm{Tyr}^{1}-\mathrm{Ala}^{2} \mathrm{Q}\left(\mathrm{CH}_{2} \mathrm{NH}\right) \mathrm{Glu}^{3}\right] \mathrm{GIP}_{1-30}} \\
{\left[(\mathrm{P}) \mathrm{Ser}^{2}\right] \mathrm{GIP}_{1-30 \mathrm{NH} 2}} \\
{\left[\mathrm{Pro}^{3}\right] \mathrm{GIP}_{1-30 \mathrm{NH} 2}} \\
{\left[\mathrm{~N}-\mathrm{MeGlu}^{3}\right] \mathrm{GIP}_{1-30}}\end{array}$ & $\begin{array}{l}\left.\mathrm{Val}^{2}\right] \mathrm{GIP}_{1-30} \\
{\left[\mathrm{Gly}^{2}\right] \mathrm{GIP}_{1-30}} \\
{\left[\mathrm{Ser}^{2}\right] \mathrm{GIP}_{1-30}} \\
{\left[\mathrm{D}-\mathrm{Tyr}^{1} \mathrm{GIP}_{1-30}\right.} \\
{\left[\mathrm{PPa}^{1}\right] \mathrm{GIP}_{1-30}} \\
{\left[\mathrm{D}-\mathrm{Glu}^{3}\right] \mathrm{GIP}_{1-30}}\end{array}$ \\
\hline
\end{tabular}

$* \mathrm{t}_{1 / 2}=137-298$ min with purified enzyme ${ }^{\#}\left[\mathrm{Tyr}^{1}-\mathrm{Ala}^{2} \square\left(\mathrm{CH}_{2} \mathrm{NH}\right) \mathrm{Glu}^{3}\right] \mathrm{GIP}_{1-30 \mathrm{NH} 2}$ : reduced peptide bond between $\mathrm{Ala}^{2}$ and $\mathrm{Glu}^{3}{ }^{\#} \mathrm{PPa}=\left(\left[\right.\right.$ Desamino $\mathrm{Tyr}^{1}$ (phenylproprionic acid)

Competitive binding and cyclic AMP stimulation studies were performed on GIP-R1 cells with all peptides. In general, when examining binding affinity, the amino-terminus of GIP was fairly tolerant of amino acid substitution or modification. With $\left[\mathrm{PPa}^{1}\right]-,\left[\mathrm{D}-\mathrm{Tyr}^{1}\right]-$, [D-Ala $\left.{ }^{2}\right]-$ and [D-Glu $\left.{ }^{3}\right]-G I P$ little or no change in binding affinity was observed. Substitutions of $\left[\mathrm{T}^{1} \mathrm{~A}^{2} \square\left(\mathrm{CH}_{2} \mathrm{NH}\right)\right]$, $\left[\mathrm{Gly}^{2}\right]$, and $\left[\mathrm{Ser}^{2}\right]$ were well tolerated with respect to binding affinity, and binding of $\left[\mathrm{Val}^{2}\right]-,\left[\mathrm{Pro}^{3}\right]-$ and $\left[\mathrm{N}-\mathrm{MeGlu}{ }^{3}\right]$-GIP was only modestly reduced. However all peptides exhibiting complete DPIV resistance, apart from [D$\left.\mathrm{Ala}^{2}\right]$ GIP, displayed dramatically reduced cyclic AMP stimulating ability. $\left[\mathrm{T}^{1} \mathrm{~A}^{2} \square\left(\mathrm{CH}^{2} \mathrm{NH}\right)\right]-,\left[\mathrm{Pro}^{3}\right]-$ and $\left[\mathrm{N}-\mathrm{MeGlu}^{3}\right]-\mathrm{GIP}$ were not even capable of achieving maximal levels. [(P)Ser $\left.{ }^{2}\right]$ GIP showed both greatly reduced binding affinity and cAMP production.

From these binding and cyclic AMP data, $\left[\mathrm{D}-\mathrm{Ala}^{2}\right] \mathrm{GIP}$ was concluded to have the greatest potential for further peptide development ${ }^{20}$. Both $\left[\mathrm{D}-\mathrm{Ala}^{2}\right] \mathrm{GIP}_{1-30}$ and [D-Ala ${ }^{2}$ GIP $_{1-42}$ were completely resistant to DPIV degradation for over 24 hours, and had minimal changes in receptor binding. When tested in vivo, [D$\mathrm{Ala}^{2}$ ]GIP reduced glycaemic excursions in Wistar rats and both lean and obese Vancouver diabetic Zucker (VDZ) rats to a greater extent than native GIP. 
This was associated with enhanced early phase insulin release in lean animals, and in diabetic rats where first phase insulin release is compromised, augmentation over the entire insulin time-course was observed. This is of particular interest since, in contrast to the lack of insulin response in fatty VDZ rats when GIP was administered to approximate physiological levels ${ }^{21}$, insulin responses could be induced with pharmacological doses.

Although $\left[\mathrm{Ser}^{2}\right] \mathrm{GIP}_{1-30 \mathrm{NH} 2}$ was only moderately resistant to DPIV degradation ( 137-686 min), it had favourable binding and signaling characteristics at the cloned GIP receptor. In studies on the degradation of glucagon ${ }^{22}$, which normally has a serine in position 2 , serine phosphorylation resulted in complete resistance to purified DPIV, and this molecule was rapidly dephosphorylated in serum. We therefore examined the effect of phosphorylation of $\mathrm{Ser}^{2}$ on the characteristics of $\mathrm{GIP}_{1-30 \mathrm{NH} 2}$. (P) $\left.\mathrm{Ser}^{2}\right] \mathrm{GIP}_{1-30 \mathrm{NH} 2}$ was completely resistant to DPIV. Although the affinity of [(P)Ser $\left.{ }^{2}\right]$ GIP was reduced 21 -fold and the concentration-response curve for cAMP production was right shifted (433fold), when $\left[\mathrm{Ser}^{2}\right] \mathrm{GIP}_{1-30 \mathrm{NH} 2}$ was administered sc during a OGTT, it resulted in a slightly more pronounced reduction in the glycaemic profile than $\mathrm{GIP}_{1-30 \mathrm{NH} 2}$, and an enhanced insulin time-course. Higher doses of [(P)Ser $\left.{ }^{2}\right]$ GIP resulted in greater reduction in the glycemic profile than $\mathrm{GIP}_{1-30 \mathrm{NH} 2}$, and significantly enhanced insulin responses. Both $\left[\mathrm{D}-\mathrm{Ala}^{2}\right] \mathrm{GIP}$ and $\left[(\mathrm{P}) \mathrm{Ser}^{2}\right] \mathrm{GIP}$ are therefore promising analogues and, along with $\left[\mathrm{Tyr}^{1}{ }^{1}\right.$-Glucitol $] \mathrm{GIP}^{23}$, may well prove useful for improving glucose tolerance in humans.

\section{DEVELOPMENT OF TRUNCATED GIP ANALOGUES}

GIP is the largest polypeptide of the glucagon-secretin family, with 42 amino acids, as compared to 30 in GLP-1 $1_{7-36}$. It would clearly be advantageous to develop truncated forms of the molecule that retain biological activity, and we performed structure-activity studies with the view to designing such analogues.

Evidence has been presented for the existence of multiple domains in $\operatorname{GIP}_{1-42}{ }^{19}$. Early studies showed that it is possible to truncate the C-terminus with retention of biological activity; synthetic $\mathrm{GIP}_{1-38}$ and $\mathrm{GIP}_{1-42}$ were shown to be equally insulinotropic ${ }^{1,2}$. Equal potency to $\mathrm{GIP}_{1-42}$ has been demonstrated for GIP $_{1-31}$ and GIP $_{1-30}$ in stimulating cyclic AMP production in insulinoma cells ${ }^{8}$ and insulin release from the perfused pancreas. However GIP $_{1-30 \mathrm{NH} 2}$ lacks gastric effects, although it is unclear whether this is due to the existence of a second GIP receptor, an alternatively spliced receptor, or differential ligand recognition and coupling of the receptor in gastric cells.

The insulinotropic domain of GIP has been localized to residues 19 to 30, consistent with partial retention of insulinotropic activity of GIP $_{19-30}$, GIP $_{15-42}$ and GIP $_{17-42}{ }^{1,19}$. Residues 27-30 may be important for biological activity, as GIP $_{1-27}$ and GIP GI-28 $_{1}$ are devoid of insulinotropic potency. Computer assisted 
secondary structure analysis of GIP predicts an alpha helical region between residues 10 and 29 (Fig. 1). Hence, it is possible that this helical structure is important for biological activity. Antagonism of the GIP receptor has been demonstrated with N-terminally truncated peptides, $\mathrm{GIP}_{6-30 \mathrm{NH} 2}, \mathrm{GIP}_{7-30 \mathrm{NH} 2}$, and GIP $_{10-30 \mathrm{NH} 2}$, and the complete high affinity binding domain of GIP resides between residues 6 and $30^{24}$. Recently, we obtained evidence for a bioactive domain of GIP residing in residues $1-14^{20}$. In binding studies, bioactivity of Nterminal GIP fragments was restricted to GIP $_{1-14}$ and amidated forms of GIP $_{1-13}$ and GIP $_{1-15}$. GIP 1-14NH2 $_{2}$ exhibits low, but significant, insulinotropic activity. Using a bioassay, both GIP $_{1-14 \mathrm{NH} 2}$ and, to a lesser extent, GIP $_{19-30 \mathrm{NH} 2}$ reduced excursions in glycaemia in an equivalent manner to $\mathrm{GIP}_{1-42 \mathrm{OH}}$, although 100 fold greater doses were needed ${ }^{20}$.

In recent studies, an alanine scan of $\mathrm{GIP}_{1-140 \mathrm{OH}}$ was performed to identify key residues contributing to biological activity. Substitution of any residue of the 114 primary sequence resulted in significantly reduced binding affinity, with the notable exception of $\left[\mathrm{Tyr}^{13}\right] \mathrm{GIP}_{1-14 \mathrm{OH}}$. The substituted analogs $\mathrm{Ala}^{1}, \mathrm{Ala}^{3}, \mathrm{Ala}^{4}$ or $\mathrm{Ala}^{5}$ were devoid of biological activity indicating that these residues are particularly important for conferring structure optimal for binding. [D-Ala ${ }^{2}$ ] substitution of $\mathrm{GIP}_{1-14 \mathrm{OH}}$ was also not well tolerated.

Given that GIP $_{1-14}$ and GIP $_{19-30}$ both demonstrate receptor binding ability, and that the high affinity binding domain of GIP resides within residues 6 to $30^{24}$, it is likely that multiple contact residues contribute to high affinity receptor binding. Additionally, the two N-terminal residues may either interact with or be in close proximity to the core region (possibly indicating the presence of a functional hinge in the alpha helices), resulting in receptor activation. Using this information it may be possible to develop more potent analogues.

\section{CONCLUSION}

Although type 2 diabetic patients exhibit resistance to GIP when the peptide is administered in doses that result in circulating levels approximating those found physiologically, it is likely that DPIV-resistant forms of the peptide administered in pharmacological doses will prove to be effective in improving glucose tolerance. Additionally, in view of recent studies showing that GIP receptor knockout mice are resistant to diet induced obesity ${ }^{25}$, it is possible that GIP antagonists will prove useful in obesity treatment.

\section{ACKNOWLEDGEMENTS}

Work by the authors described in this review was funded by the Canadian Institutes of Health Research (RAP and CHSM Grant \#MOP-13192) and the 
Department of Science and Technology of Sachsen Anhalt (HUD \# 9704/00116).

\section{REFERENCES}

1. Brown J.C., Buchan, A.M.J., McIntosh, C.H.S., and Pederson R.A. 1989. Gastric inhibitory polypeptide. In Handbook of Physiology, Section 6 the Gastrointestinal System (S.G. Schultz, G.M. Makhlouf, and B.B. Rauner), Am. Physiol. Soc., Bethesda pp. 403-430.

2. Pederson, R.A. 1994, GIP. In Gut Peptides: Biochemistry and Physiology (J.H. Walsh and G.J. Dockray, eds.), Raven Press, New York, pp. 217-259.

3. Holst, J.J. 1999. Glucagon-like peptide 1 (GLP-1): an intestinal hormone signaling nutritional abundance, with an unusual therapeutic potential. Trends Endocrinol. Metab. 10: 229-234.

4. Meier, J.J., Nauck, M.A., Schmidt, W.E. and Gallwitz, B. 2002. Gastric inhibitory polypeptide: the neglected incretin. Reg. Peptides 107: 1-13.

5. Trümper, A., Trümper, K., Trusheim, H., Arnold, R., et al. 2001.Glucose-dependent insulinotropic polypeptide is a growth factor for $\square$ (INS-1) cells by pleiotropic signaling. Mol. Endocrinol. 15: 1559-1570.

6. Ehses, J., Casilla, V., Doty, T., Pospisilik, J.A., Demuth, H.-U., Pederson, R.A. and McIntosh, C.H.S. 2002. Glucose-dependent Insulinotropic Polypeptide (GIP) stimulates cell growth and promotes cell survival in INS-1 cells. Diabetes 51:A339.

7. Jia, X., Brown, J.C., Ma P., Pederson, R.A., and McIntosh, C.H.S. 1995. The effects of glucose dependent insulinotropic polypeptide and glucagon-like peptide-1(7-36) on insulin secretion. Am. J. Physiol 268: E645-E651.

8. Wheeler, M.B., Gelling, R.W., McIntosh, C.H.S., Georgiou, J., Brown, J.C. and Pederson, R.A. 1995 Functional expression of the rat pancreatic islet glucose-dependent insulinotropic polypeptide (GIP) receptor: Ligand binding and intracellular signaling properties. Endocrinology 136: 4629-4639.

9. McIntosh, C.H.S., Bremsak, I., Lynn, F.C., Gill R., Hinke, S.A., Gelling, R., McKnight, G., Jaspers, S., Pederson, R.A. 1999. Glucose dependent insulinotropic polypeptide stimulation of lipolysis in differentiated 3T3-L1 cells: wortmannin-sensitive inhibition by insulin. Endocrinology 140: 398-404.

10. Brown, J.C., Dahl, M., Kwauk, S., McIntosh, C.H.S., Ottte, S.C. and Pederson, R.A., 1981, Actions of GIP. Peptides 2 (Suppl. 2): 241-245.

11. Jörnvall, H., Carlquist, M., Kwauck, S., Otte, S.C., McIntosh, C.H.S., Brown, J.C. and Mutt, V. 1981. Amino acid sequence and heterogeneity of gastric inhibitory polypeptide (GIP). FEBS Lett. 123: 205-210.

12. Mentlein, R., Gallwitz, B. and Schmidt, W.E. 1993. Dipeptidyl peptidase IV hydrolyses gastric inhibitory polypeptide, glucagon-like peptide-1 (7-36)amide, peptide histidine methionine and is responsible for their degradation in human serum. Eur. J. Biochem. 214: 829-835.

13. Kieffer, T.J. McIntosh, and Pederson, R.A. 1995. degradation of glucose-dependent 
insulinotropic polypeptide and truncated glucagon-like peptide 1 in vitro and in vivo by dipeptidyl peptidase IV. Endocrinology 136: 3585-3596.

14. Perley, M.J., and Kipnis, D.M. 1967. Plasma insulin responses to oral and intravenous glucose: studies in normal and diabetic subjects. J. Clin. Invest. 46: 1954-1962.

15. Jones, I.R., Owens, D.R., Moody, A.J., Luzio, S.D., et al. 1987. The effects of glucose dependent insulinotropic polypeptide infused at physiological concentrations in normal subjects and type 2 (non-insulin-dependent) diabetic patients on glucose tolerance and B-cell secretion. Diabetologia 30: 707-712.

16. Meneilly, G.S., Bryer-Ash, M. and Elahi, D. 1993. The effect of glyburide on B-cell sensitivity to glucose-dependent insulinotropic polypeptide. Diabetes Care 16: 110-114.

17. Nauck, M., Heimesaat, M.M., Ørskov, C., Holst, J.J., Ebert, R. and Creutzfeldt, W. Preserved incretin activity of glucagon-like peptide 1 [7-36 amide] but not of synthetic human gastric inhibitory polypeptide in patients with type-2 diabetes mellitus. J. Clin. Invest. 91: 301-307.

18. Kühn-Wache, K., Manhart, S., Hoffmann, T., Hinke, S.A., Gelling, R., Pederson, R.A., McIntosh, C.H.S. and Demuth, H-U. 2000. Analogs of glucose-dependent insulinotropic polypeptide with increased dipeptidyl peptidase resistance. Adv. Exp. Med. Biol. 477: 187195.

19. Hinke, A.A., Manhart, S., Pamir, N., Demuth, H.-U., Gelling, R.W., Pederson, R.A. and McIntosh. C.H.S. 2001. Identification of a bioactive domain in the amino-terminus of glucose-dependent insulinotropic polypeptide (GIP) Biochim. Biophys. Acta 364: 1-13.

20. Hinke, S.A., Gelling, R.W., Pederson, R.A., Manhart, S, Nian, C., Demuth, H.-U. and McIntosh, C.H.S. Dipeptidyl peptidase IV-resistant [D-Ala ${ }^{2}$ glucose-dependent insulinotropic polypeptide (GIP) improves glucose tolerance in normal and obese diabetic rats. Diabetes 51: 652-661, 2002.

21. Lynn, F.C., Pamir, N., Ng, E.H.C., McIntosh, C.H.S., and Pederson, R.A. 2001. Defective glucose-dependent insulinotropic polypeptide receptor expression in diabetic fatty Zucker rats. Diabetes 50:1004-1011.

22. Hinke, S. A., Pospisilik,J.A., Demuth, H.-U., Mannhart, S., Kühn-Wache, K., Hoffmann, T., Nishimura, E., Pederson, R. A. and McIntosh, C.H.S. 2000. Dipeptidyl peptidase IV (DPIV/CD26) degradation of glucagon. J. Biol. Chem. 275: 3827-3834.

23. O'Harte, F., Mooney, M. and Flatt, P. 1999. $\mathrm{NH}_{2}$-terminally modified gastric inhibitory polypeptide exhibits amino-peptidase resistance and enhanced antihyperglycemic activity. Diabetes 48: 758-765.

24. Gelling R.W., Coy D., Pederson R.A., Wheeler M.B., O'Dorisio T., Hinke S. and McIntosh C.H.S. 1997. GIP $6-30$ amide contains the high affinity binding region of GIP and is a potent inhibitor of GIP1-42 action in vitro. Reg. Peptides 69: 151-154.

25. Miyawaki, K., Yamada, Y., Ban, N., Ihara, Y., Tsukiyama, K., Zhou, H., Fujimoto, S., Oku, A., Tsuda, K. et al. Inhibition of gastric inhibitory polypeptide signaling prevents obesity. Nature Med. 8: 738-742. 
